\title{
Facial and Skeletal Muscle Magnetic Resonance Imaging in Oculopharyngodistal Myopathy
}

\author{
Okülofaringodistal Miyopatide Yüz ve Ekstremite Kaslarının Manyetik Rezonans
} Görüntülemesi

\author{
Hacer Durmuş ${ }^{1}$, Memduh Dursun ${ }^{2}$, Serra Sencer ${ }^{2}$, Feza Deymeer ${ }^{1}$, Piraye Oflazer-Serdaroğlu1 \\ 1 İstanbul Üniversity İstanbul Faculty of Medicine, Department of Nöurology, İstanbul, Turkey \\ 2istanbul Üniversity İstanbul Faculty of Medicine, Department of, Radiological , İstanbul, Turkey
}

\section{Summary}

Objective: Oculopharyngodistal myopathy (OPDM) has been reported as a rare, adult-onset hereditary muscle disease. Patients show progressive oculopharyngeal and distal limb muscle involvement. As the genetic defect underlying OPDM is not known yet, the diagnosis currently rests upon clinical and histopathological features. This study was aimed at investigating patterns of muscle alterations of OPDM patients by MRI and to search for possible clues to make differential diagnosis by using a non-invasive method.

Materials and Methods: Facial, upper and lower extremity muscles of 10 patients with OPDM, followed by the Neuromuscular Unit, Department of Neurology, Istanbul Faculty of Medicine, who had undergone detailed evaluation with manual muscle testing and who had different disease severity were evaluated with MRI using conventional T1 and T2 weighted axial images. The degree of muscle involvement on MRI was evaluated according to a modified 5-point scale in extremities and 6-point scale in facial muscles.

Results: The mean age of onset was $20.1 \pm 8.2$ years (range 7-39 years) and the mean disease duration was $14.5 \pm 12.4$ years (range 2-41 years). Seven patients showed dominantly distal, one patient dominantly proximal weakness and two patients had no weakness. The patients without weakness had normal imaging, but facial muscle MRI from one of them revealed mild involvement. Zygomatic and nasal muscles were the most severely and earliest involved muscles in face. MRI of all patients with muscle weakness showed a consistent selective extremity muscle involvement pattern. Distal extremity muscles were more affected than proximal muscles. Earliest and most sever changes were found in semimembranosus, biceps femoris and medial head of gastrocnemius, soleus. Interestingly, sartorius, gracilis and semitendinous muscles and the lateral head of gastrocnemius were well-preserved in OPDM.

Conclusion: Muscle MRI by showing selective involvement of exteremity muscle may be a non-invasive tool in the differential diagnosis of OPDM. (Turkish Journal of Neurology 2014; 20:121-125)

Key Words: Oculopharyngodistal, myopathy, magnetic resonance imaging

Conflict of interest: The authors reported no conflict of interest related to this article.

\section{Özet}

Amaç: Okülofaringodistal miyopati (OFDM) erişkin başlangıçlı, nadir, kalıtsal bir kas hastalığıdır. Hastalarda yavaş ilerleyici okülofaringeal tutulum ve distal kaslarda zaaf gözlenir. Altta yatan genetik defektin henüz bilinmemesi nedeniyle OFDM'de tanı günümüzde klinik ve histopatolojik özelliklere dayanmaktadır. Bu çalışmada, OFDM'li hastalarda noninvazif bir yöntem olan manyetik rezonans görüntüleme (MRG) ile kaslardaki değişiklikleri araştırmak ve ayrıcı tanı ipuçları sağlamak amaçlanmıştır.

Gereç ve Yöntem: İstanbul Üniversitesi İstanbul Tıp Fakültesi, Nöroloji Ana Bilim Dalı, Nöromüsküler Hastalıklar Polikliniğinden takipli, farklı hastalık şiddet ve süresine sahip, ayrıntılı nörolojik muayene yapılmış olan 10 OFDM'li hastanın yüz kasları ile üst ve alt ekstremite kasları konvansiyonel T1 ve T2 ağırlıklı aksiyel kesitler alınarak görüntülenmiştir. Yağlı dejenerasyon miktarı göz önünde tutularak ekstremite kaslarına ait olan görüntüler 5, yüz kaslarına ait olan görüntüler ise 6 dereceli skalalar ile değerlendirilmiştir.

Bulgular: Kohortumuzda semptomların başlangıç yaşı 20,1 $\pm 8,2$ (7-39 yaş arasında), ortalama hastalık süresi 14,5 $\pm 12,4$ (2-41 yıl arasında) idi. Yedi hastada distal, bir hastada proksimal ağırlıklı zaaf saptanırken, iki hastada ekstremite zaafı bulunmadı. Ekstremite zaafı bulunmayan hastaların ekstremite görüntülemeleri normal sınırlardaydı ancak bu hastaların birinde yüz kaslarında tutulum gözlendi. En erken ve en şiddetli tutulan yüz kasları zigomatik ve nasal kaslar idi. Ekstremite zaafı

Address for Correspondence/Yazışma Adresi: Hacer Durmuş MD, İstanbul Üniversity İstanbul Faculty of Medicine, Department of Nöurology, İstanbul, Turkey Gsm: +90 5079477427 E-mail: durmushacer@yahoo.com

Received/Geliş Tarihi: 20.10.2014 Accepted/Kabul Tarihi: 06.11.2014 


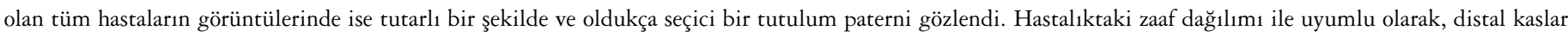

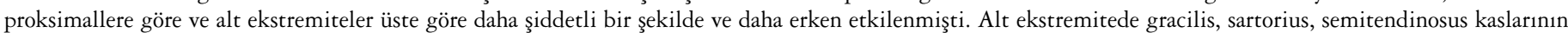

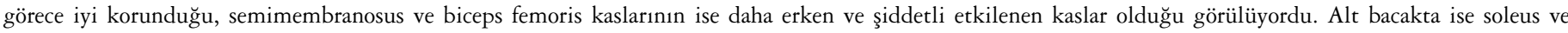
gastrocnemius medialis kaslarının, OFDM'de en erken ve en şiddetli etkilenen kaslar olduğu, gastrocnemius lateralis başının ise korunduğu gözlendi.

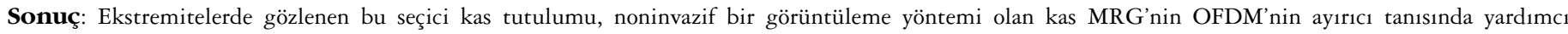
olabileceğini düşündürmektedir. (Türk Nöroloji Dergisi 2014; 20:121-125)

Anahtar Kelimeler: Okülofaringodistal, miyopati, manyetik rezonans

Çıkar çatışması: Yazarlar bu makale ile ilgili olarak herhangi bir çıkar çatışması bildirmemişlerdir.

\section{Introduction}

Oculopharyngodistal myopathy (OPDM), first identified by Satoyoshi and Kinoshita, is an extremely rare, early-adult onset, hereditary myopathy that can be inherited either as autosomal dominant (AD) or autosomal recessive (AR) (1). Until today, only 29 OPDM from 14 different families were reported $(1,2)$. The largest series with 47 patients was identified in Turkey when its phenotype was also detailed and the disease was genetically shown to be a separate myopathy (3). Progressive oculopharyngeal and distal muscle weakness is the most prominent characteristic of the disease. Patients become unable to walk within 20 years of the onset of symptoms. Red bordered vacuoles that are seen also in other myopathies, as well as other myopathic changes in varying degrees, are also seen in the muscle biopsies of patients with OPDM. Since the genetic defect causing the disease is still not known, the diagnosis of OPDM relies on clinical and histopathological studies.

In the light of the recent advancements in the genetic diagnosis of hereditary neuromuscular diseases that took place in the past ten years, however, non-invasive imaging of the severity and the pattern of disease-specific muscle involvement enabled differential diagnosis using these methods. Magnetic resonance imaging (MRI) has replaced ultrasonography and computerized tomography that were used in 1980s.

In our study, we aimed to investigate the muscle changes in OPDM using MRI; compare our findings with MRI studies on diseases that would create problems in differential diagnosis such as oculopharyngeal muscular dystrophy (OPMD), myotonic dystrophy type-1 (DM1) and facioscapulohumeral dystrophy (FSHD), and thus provide clues for differential diagnosis using a non-invasive method.

\section{Materials and Methods}

Our study included 10 unrelated patients with varying disease severity coming from 5 different families living in different parts of Turkey who visited Istanbul University Faculty of Medicine Department of Neurology, Neuromuscular Diseases Policlinic between the dates 1982 and 2009.

Informed consents from the patients were acquired in compliance with Helsinki Declaration (BMJ 1991; 302: 1194) after receiving approval from Istanbul University, Faculty of Medicine Ethical Board.

In all families included in the study, OPMD, DM1 and FSHD diagnoses were genetically excluded.

Facial, upper and lower extremity muscles were scanned using 1.5 Tesla Philips Achieva MR device and T1 and T2 weighted sequences. Imaging volumes of the extremity muscles were evaluated using a 5-point scale for the amount of fatty degeneration; normal "N"; traces of increased T1 signal intensity, mild " 1 "; obvious increase in T1 signal intensity and confluence of these lesions (less than $50 \%$ of the muscle), medium " 2 "; obvious increase in T1 signal intensity and confluence on more than $50 \%$ of the muscle, severe " 3 "; complete fatty degeneration, very severe " 4 ". For facial muscles, more fine-grained changes were taken into consideration and the evaluation was made using a 6-point scale.

\section{Discussion}

In our study, facial and extremity MRIs of OPDM patients with varying severity of disease were evaluated. Average age of onset was $20.1 \pm 8.2$ (between ages 7-39) with average disease duration being $14.5 \pm 12.4$ ( $1-41$ years). Four of the patients were female while 6 were male. Two patients showed autosomal recessive (AR) inheritance; hereditary pattern for one patient was unclear and other 7 patients had autosomal dominant (AR) inheritance. All patients had facial involvement. There were extremity weaknesses predominantly distal but in varying degrees in seven patients, predominantly proximal weakness in one patient, and no extremity weakness in two patients. One of the patients (Patient 8) was in a wheelchair for the past 2 years and Patient 10 could only walk with bilateral support. The clinical details for the patients were summarized in Table 1.

\section{Extremity Muscle Findings}

Extremity MRIs of two patients (Patients 1 and 2) who were in the second year of the disease and who showed facial involvement but no muscle weaknesses were completely normal. In two earlystage patients whose disease durations were under 10 years (Patients 3 and 4), upper extremity muscles were normal but hamstring muscles were the first ones to be affected in the lower extremity proximal (especially semimembranosus and the long head of biceps femoris). Gastrocnemius' medial head and soleus, peroneus longus, peroneus brevis and tibialis posterior were affected at first. In addition to these muscles, for patients whose disease duration were 10-16 years, four patients who had moderate weakness in distal extremities but who could walk without aid (Patients 5, 6, 7, 9), it was seen that forearm and hand muscles on the upper extremities and hamstrings on the lower extremities were also affected but quadriceps femoris also began to show changes. In two patients whose disease duration were over 20 years (Patients 8 and 9), all distal and proximal muscles were affected to varying degrees. As a noteworthy finding for these two patients, however, iliopsoas, quadriceps femoris, gracilis, sartorius and semitendinosus were relatively preserved. 
Table 1. Clinical properties of 10 oculopharyngodistal myopathy patients who had magnetic resonance imaging of facial and extremity muscles

\begin{tabular}{|c|c|c|c|c|c|c|c|}
\hline Patient no: & Age (year) & Sex & $\begin{array}{c}\text { Disease } \\
\text { duration } \\
\text { (year) }\end{array}$ & Inheritance & $\begin{array}{c}\text { Facial } \\
\text { involvement }\end{array}$ & Weakness distribution & $\begin{array}{l}\text { Onset } \\
\text { finding }\end{array}$ \\
\hline 1 & 8 & $\mathrm{M}$ & 2 & $\mathrm{AD}$ & + & No extremity weatness & Ptosis \\
\hline 3 & 27 & M & 4 & $\mathrm{AD}$ & + & Mild distal weakness & Ptosis \\
\hline 4 & 30 & M & 9 & $\mathrm{AD}$ & + & Distal. unaided walk & Dysphagia \\
\hline 5 & 35 & $\mathrm{~F}$ & 14 & $\mathrm{AD}$ & + & Distal. unaided walk & Ptosis \\
\hline 8 & 45 & M & 29 & $\mathrm{AD}$ & + & D>P. 43 years old. uses wheelchair & Nasal speech \\
\hline 9 & 52 & M & 13 & Sporadic & + & Distal. unaided walk & Ptosis \\
\hline 10 & 59 & K & 41 & OD & + & $\begin{array}{c}\text { Lower extremity } \mathrm{P}>\mathrm{D} \text {. Upper } \\
\text { extremity } \mathrm{D}>\mathrm{P} \text {. Requires walking } \\
\text { aid. }\end{array}$ & Ptosis \\
\hline
\end{tabular}

F: Female, M: Male, AD: Autosomal dominant, AR: Autosomal recessive, D: Distal, P: Proximal

Table 2. Median values of extremity magnetic resonance imaging scores of patients whose disease durations are over or under 15 years

\begin{tabular}{lcc}
\hline & $\begin{array}{c}\text { Disease } \\
\text { duration } \\
<15\end{array}$ & $\begin{array}{c}\text { Disease } \\
\text { duration } \\
>15\end{array}$ \\
\hline Deltoideus & 0 & 1 \\
Biceps & 0 & 0.5 \\
Triceps & 0 & 0 \\
Interosei & 0 & 1 \\
Iliopsoas & 0 & 1 \\
Gluteus maximus & 0 & 2 \\
Quadriceps femoris & 0 & 0.5 \\
Sartorius & 0 & 1 \\
Gracilis & 0 & 1 \\
Biceps femoris short head & 0 & 1 \\
Biceps femoris long head & 0.5 & 3 \\
Semitendinosus & 0 & 1.5 \\
Semimembranosus & 0.5 & 2 \\
Gastrocnemius medialis & 1 & 3.5 \\
Gastrocnemius lateralis & 0 & 0.5 \\
Solues & 1.5 & 4 \\
Tibialis anterior & 0 & 1.5 \\
Peroneus longus & 0.5 & 2 \\
Tibialis posterior & 0 &
\end{tabular}

When the MRI staging median scores of patients with disease duration of less than 15 years (Patients 1, 2, 3, 4, 5, 9) and more than 15 years (Patients 6, 7, 8, 10) were compared, it was seen that all of the muscles of patients with $>15$ years of the disease had some involvement, whereas those $<15$ years of the disease had mostly biceps femoris long head, semimembranosus, gastrocnemius medial head, solues and peronealis longus as the earliest involved muscles (Table 2).
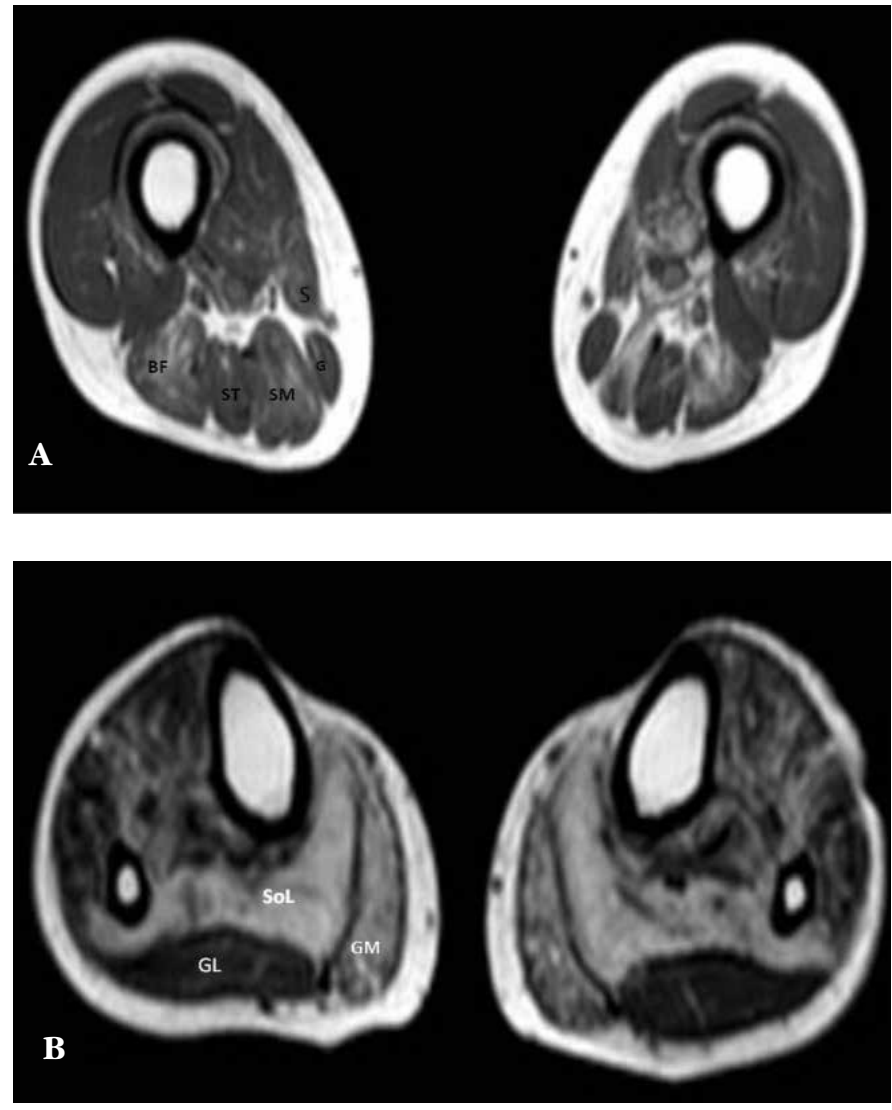

Figure 1. Selective muscle involvement in a patient (Patient 9) with 13 years of oculopharyngodistal myopathy disease (A, B): Soleus muscle (SoL), gastrocniemius medial head (GM), semimembranosus (SM), and biceps femoris (BF) are the most severely involved muscles. Gastrocnemius lateral head (GL), grasilis (G), sartorius (S), semitendinosus (ST) and biceps brachii short head are relatively preserved 


\section{Facial Muscle Findings}

Facial muscles of the patients were evaluated with a system similar to the one reported above, but with 6 points. Detailed results of face MRIs are given in Table 2. In one of the two earlystage patients who did not show extremity muscle involvement, there was facial involvement (Patient 1). Zygomaticus and nasalis muscles were the earliest and most severely affected muscles but all other muscles over were involved over the course of the disease in different amounts. Sternocleidomastoideus muscle was preserved until the late stages of the disease. The selective involvement of the paravertebral muscles, especially the anterior ones, was limited until the late stages of the disease. But the fact that posterior paraventral muscles were markedly involved is a noteworthy finding (Table 3).

\section{Results}

Since the genetic defect causing OPDM is still unknown, the diagnosis of the disease is currently based on clinical and histopathological evidence. Due to the fact that muscle pathology is an invasive method, there is evidence suggesting that muscle MRI studies in patients whose definitive diagnosis had been made with genetic methods may help with differential diagnosis of muscle diseases (4).

Upper and lower extremity muscle imaging of two patients who did not have any extremity weaknesses, patients 1 and 2, were normal. All other patients who had visible muscle weaknesses had distinct and selective involvement patterns in their muscle MRI: lower extremity muscles, in comparison to the upper ones, were involved much earlier and more severely but in congruence with the weakness distribution of the disease, distal muscles were affected more severely or earlier as compared to proximal ones in both lower and upper extremities. Dorsal compartment muscles on the lower extremity proximal were much severely involved compared to anterior ones; semimembranosus and biceps femoris muscles were involved earlier and more severely (Figure 1A). In lower leg, soleus and medial gastrocnemius muscles were seemingly the most severely involved muscle groups in OPDM (Figure 1B). The details of the extremity MRI findings are provided in Table 3. Upper extremity did not show any selective involvement patterns that would provide clues for differential diagnosis.

In this study recruiting 10 patients among our general cohort who are at different stages of the disease, the earliest involvement is seen in soleus and medial gastrocnemius muscles on the lower

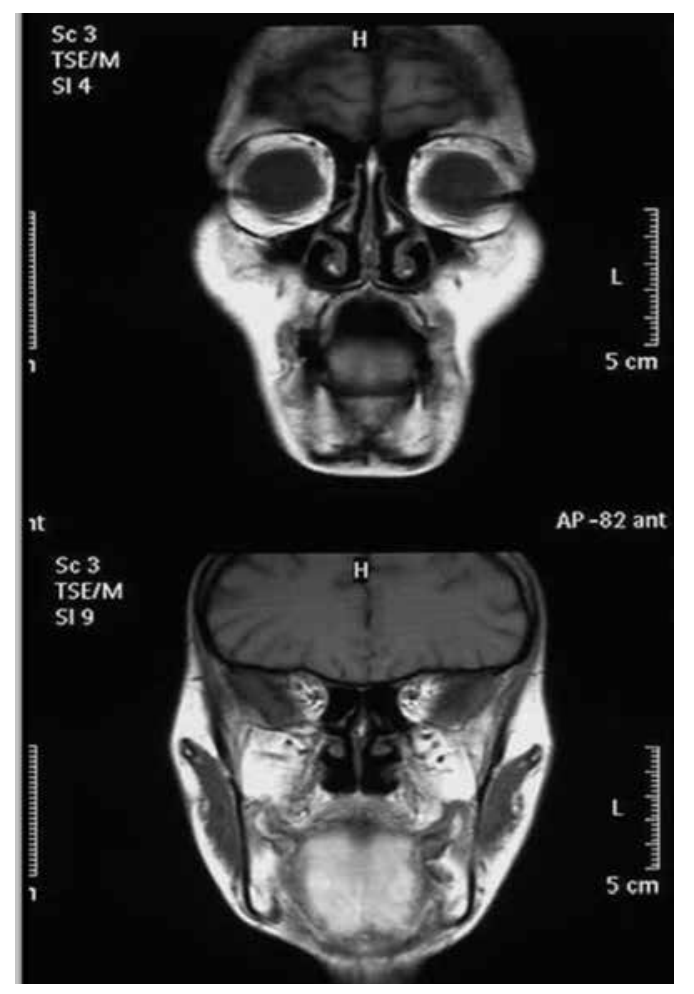

Figure 2. Involvement of facial muscles in oculopharyngodistal myopathy. Early stage zygomaticus and nasalis muscle involvement in a patient in the 4 th year of the disease

Table 3. Details of the facial MRI of 10 patients

\begin{tabular}{|c|c|c|c|c|c|c|c|c|c|c|}
\hline & 1 & 2 & 3 & 4 & 5 & 6 & 7 & 8 & 9 & 10 \\
\hline Sternocleidomastoideus & $\mathbf{N}$ & $\mathbf{N}$ & $\mathbf{N}$ & 2 & 1 & 2 & 3 & 4 & 4 & 4 \\
\hline \multicolumn{11}{|l|}{ Paravertebral } \\
\hline anterior & $\mathrm{N}$ & $\mathrm{N}$ & $\mathrm{N}$ & $\mathrm{N}$ & $\mathrm{N}$ & $\mathrm{N}$ & 1 & $\mathrm{~N}$ & 1 & 1 \\
\hline posterior & 2 & $\mathrm{~N}$ & 1 & 3 & 3 & 4 & 4 & 4 & 4 & 4 \\
\hline Periorbital muscles & 1 & $\mathrm{~N}$ & $\mathrm{~N}$ & 1 & 2 & 3 & 3 & 4 & 4 & 4 \\
\hline Perioral muscles & 1 & $\mathrm{~N}$ & $\mathrm{~N}$ & 1 & 3 & 3 & 4 & 3 & 4 & 5 \\
\hline Zygomaticus & 3 & $\mathrm{~N}$ & 4 & 3 & 5 & 4 & 5 & 5 & 5 & 5 \\
\hline Nasalis & 3 & $\mathrm{~N}$ & 4 & 3 & 5 & 4 & 5 & 5 & 5 & 5 \\
\hline Masseter & 2 & $\mathrm{~N}$ & 1 & 1 & 4 & 3 & 3 & 4 & 4 & 5 \\
\hline Temporal & 2 & $\mathrm{~N}$ & 3 & 2 & 4 & 5 & 4 & 5 & 4 & 5 \\
\hline Intrinsic tongue muscles & 2 & $\mathrm{~N}$ & 2 & 3 & 5 & 5 & 5 & 5 & 5 & 5 \\
\hline Mouth floor muscles & 2 & $\mathrm{~N}$ & $\mathrm{~N}$ & 3 & 5 & 4 & 4 & 1 & 4 & 4 \\
\hline \multicolumn{11}{|l|}{ Pterygoideus } \\
\hline Medialis & $\mathrm{N}$ & $\mathrm{N}$ & 1 & 2 & 2 & 3 & 5 & 1 & 2 & 5 \\
\hline Lateralis & $\mathrm{N}$ & $\mathrm{N}$ & 1 & 2 & 3 & 4 & 5 & 2 & 3 & 5 \\
\hline
\end{tabular}


extremities. This involvement pattern is seen also in many other myopathies and dystrophies and it does not provide much utility for differential diagnosis (12). For upper extremity, there was not a selective involvement pattern in MRI. However, it may be possible that the selective involvement pattern observed in the lower proximal extremities, that is the preservation of grasilis, sartorius and semitendinosus muscles and early and more severe involvement of semimembranosus and biceps femoris muscles, may provide some utility for differential diagnosis.

All of our patients showed facial muscle weakness. Except for one early-stage patient who had very mild facial involvement and no extremity weakness, all patients showed severe facial muscle involvement.

The biggest obstacle in the differential diagnosis of OPDM is DM1. Bigger involvement for anterior femoral compartment's compared to dorsal one in MRI studies of DM1 and the relative preservation of rectus femoris constitute differences from out OPDM group (5). For that reason, MRI investigation of proximal muscles may differentiate OPDM patients from DM1 ones. While it is easier to differentiate FSHD from OPDM clinically, it should be included in the table because of its facial involvement. The MRI literature on FSHD showed medial gastrocnemius, tibialis anterior and soleus involvement in the lower half of the leg, and frequent involvement of semimembranosus in the femoral region, followed by biceps femoris, semimembranosus and the adductor muscle group. The involvement is asymmetrical, in congruent with the clinical manifestation of the disease. These properties of FSHD observed in MRI are distinctly different than those of OPDM's muscle involvement pattern (6). Another problem for the differential diagnosis in OPDM is the limited number of studies on the MRI characteristics of the disease. These studies showed abnormal fat infiltration in tongue, masseter, neck, shoulder joint, lumbar paraspinal and gluteus muscles (7). Even though literature suggest that myotilinopathy may show extremity muscle involvement patterns similar to our patients, myotilinopathies are myopathies that are genetically and clinically extremely dissimilar to OPDM, and differential diagnosis is possible on the basis of clinical evidence (8).

Facial atrophy in OPDM is a typical, differentiating but underreported property of the disease. Our findings suggests that this facial muscle involvement starts in the very early years of the disease and how dramatic it can get. A similar selective involvement was also seen in paravertebral muscles in our patient group. The selectivity in this region is in the form of much early and severe involvement of posterior group muscles as opposed to anterior ones. Due to the lack of MRI studies targeting this region, it is impossible to conclude to what extent can facial MRI contribute to the differential diagnosis with other diseases that also cause facial involvement. However, the fact that sternocleidomastoidus muscle is not involved until the late stages of the disease may provide clues in differentiating OPDM from DM1. It is necessary to adapt the facial MRI aspect of our study to other disease groups and compare the result.
In conclusion, despite the small number of patients our study had, the consistent and selective involvement pattern observed especially in the lower extremity femoral muscles suggests that non-invasive methods such as facial and extremity MRI may provide value over invasive methods in aiding the differential diagnosis of OPDM.

\section{References}

1. Satoyoshi E, Kinoshita M. Oculopharyngodistal myopathy: report of four families. Arch Neurol 1977;34:89-92.

2. Uyama E, Uchino M, Chateau D, Tomé FM. Autosomal recessive oculopharyngodistal myopathy in light of distal myopathy with rimmed vacuoles and oculopharyngeal muscular dystrophy. Neuromuscul Disord 1998;8:119-125.

3. Jaspar HH, Bastiaensen LA, ter Laak HJ, Joosten EM, Horstink MW, Stadhouders AM. Oculopharyngodistal myopathy with early onset and neurogenic features. Clin Neurol Neurosurg 1977;80:272-282.

4. Scrimgeour EM, Mastaglia FL. Oculopharyngeal and distal myopathy: a case study from Papua New Guinea. Am J Med Genet 1984;17:763-771.

5. Goto I, Kanazawa Y, Kobayashi T, Murai Y, Kuroiwa Y. Oculopharyngeal myopathy with distal and cardiomyopathy. J Neurol Neurosurg Psychiatry 1977; 40:600-607.

6. Amato AA, Jackson C, Ridings L, Barohn R. Childhood-onset oculopharyngodistal myopathy with chronic intestinal pseudo-obstruction. Muscle Nerve 1995;18:842-847.

7. Minami N, Ikezoe K, Kuroda H, Nakabayashi H, Satoyoshi E, Nonaka I. Oculopharyngodistal myopathy is genetically heterogeneous and most cases are distinct from oculopharyngeal muscular dystrophy. Neuromuscul Disord 2001;11:699-702.

8. Van der Sluijs BM, ter Laak HJ, Scheffer H, van der Maarel SM, van Engelen BG. Autosomal recessive oculopharyngodistal myopathy: a distinct phenotypical, histological, and genetic entity. J Neurol Neurosurg Psychiatry 2004;75:14991501 .

9. Witoonpanich R, Phankhian S, Sura T, Lertrit P, Phudhichareonrat S. Oculopharyngodistal myopathy in a Thai family. J Med Assoc Thai 2004;87:1518-1521.

10. Lu H, Luan X, Yuan Y, Dong M, Sun W, Yan C. The clinical and myopathological features of oculopharyngodistal myopathy in a Chinese family. Neuropathology 2008;28:599-603.

11. Durmus H, Laval SH, Deymeer F, Parman Y, Kiyan E, Gokyigiti M, Ertekin C, Ercan I, Solakoglu S, Karcagi V, Straub V, Bushby K, Lochmüller H, Serdaroglu-Oflazer P. Oculopharyngodistal myopathy is a distinct entity: clinical and genetic features of 47 patients. Neurology 2011;18:76:227-235.

12. Mercuri E, Jungbluth $H$, Muntoni $F$. Muscle imaging in clinical practice: diagnostic value of muscle magnetic resonance imaging in inherited neuromuscular disorders. Curr Opin Neurol 2005;18:526-537.

13. Castillo J, Pumar JM, Rodríguez JR, Prieto JM, Arrojo L, Martínez F, Noya M. Magnetic resonance imaging of muscles in myotonic dystrophy. Eur J Radiol 1993;17:141-144.

14. Olsen DB, Gideon P, Jeppesen TD, Vissing J. Leg muscle involvement in facioscapulohumeral muscular dystrophy assessed by MRI. J Neurol 2006;253:1437-1441.

15. King MK, Lee RR, Davis LE. Magnetic resonance imaging and computed tomography of skeletal muscles in oculopharyngeal muscular dystrophy. J Clin Neuromuscul Dis 2005;6:103-108.

16. Fischer D, Kley RA, Strach K, Meyer C, Sommer T, Eger K, Rolfs A, Meyer W, Pou A, Pradas J, Heyer CM, Grossmann A, Huebner A, Kress W, Reimann J, Schröder R, Eymard B, Fardeau M, Udd B, Goldfarb L, Vorgerd M, Olivé $\mathrm{M}$. Distinct muscle imaging patterns in myofibrillar myopathies. Neurology 2008;71:758-765. 